\title{
MTHFR and F5 genetic variations have association with preeclampsia in Pakistani patients: a case control study
}

\author{
Feriha Fatima Khidri ${ }^{1,2}$, Yar Muhammad Waryah ${ }^{1,3}$, Faiza Kamran Ali ${ }^{4}$, Hina Shaikh ${ }^{1}$, Ikram Din Ujjan ${ }^{5}$ and
} Ali Muhammad Waryah, ${ }^{1,5^{*}}$ (D)

\begin{abstract}
Background: To study the role of single nucleotide variants (SNVs) of genes related to preeclampsia in Pakistani pregnant women.

Methods: After ethical approval and getting informed consent; 250 pregnant women were enrolled and equally divided into two groups (125 preeclamptic cases and 125 normotensive pregnant women). Demographic details and medical history were recorded, and $10 \mathrm{ml}$ blood sample was obtained for DNA extraction. The tetra-primer amplification refractory mutation system (ARMS) assays were developed for assessing the variants of three preeclampsia related genes; F5, MTHFR and VEGFA. An association of six SNVs; F5:C.1601G > A (rs6025), F5:c.6665A > G (rs6027), MTHFR: c.665C > T (rs1801133), MTHFR: c.1286A > C (rs1801131), VEGFA: c.-2055A > C (rs699947) and VEGFA: c.*237C > T (rs3025039) with preeclampsia was determined by using different genetic models.

Results: Genotyping of the SNVs revealed that patients with MTHFR:c.665C > T, have increased susceptibility to preeclampsia (CT versus CC/TT: $\mathrm{OR}=2.79,95 \% \mathrm{Cl}=1.18-6.59 ; P^{*}=0.046$ and $\mathrm{CT} / \mathrm{TT}$ vs CC: $\mathrm{OR}=2.91,95 \% \mathrm{Cl}=1.29-$ 6.57; $P^{*}=0.0497$, in overdominant and dominant models, respectively), whereas $F 5: c .6665 A>G$, (A/G vs AA/GG: $\mathrm{OR}=0.42,95 \% \mathrm{Cl}=0.21-0.84 ; P^{*}=0.038$ in overdominant model) and MTHFR:C.1286A $>C$, (CC versus AA: OR=0.36, $95 \% \mathrm{Cl}=0.18-0.72 ; P^{*}=0.0392$ in codominant model) have significantly decreased risk for preeclampsia. $F 5$ : c.1601G > A, VEGFA: c.-2055A > C and VEGFA: C. 237 C > T variants revealed no relationship with the disease.

Conclusion: This is the first case control study describing the protective role of $F 5: c .6665 \mathrm{~A}>\mathrm{G}$ against preeclampsia in any world population. In addition, the present study confirmed the association and role of MTHFR gene variations in the development of preeclampsia in Pakistani patients. Further genetic studies may be required to better understand the complex genetic mechanism of SNVs in preeclampsia related genes in pregnant women.
\end{abstract}

Keywords: F5, MTHFR, Pakistan, Preeclampsia, Variants, VEGFA

\section{Background}

Preeclampsia has been estimated to affect $2-8 \%$ of pregnancies, causing $10-15 \%$ of maternal deaths worldwide $[1,2]$. It is a multifactorial and complex disorder and various studies have proposed genetic, environmental, immunological and nutritional factors for its occurrence, though the exact cause largely remains debatable [3-5].

\footnotetext{
* Correspondence: aliwaryah@lumhs.edu.pk

${ }^{1}$ Molecular Biology and Genetics Department, Medical Research Center,

Liaquat University of Medical and Health Sciences, Jamshoro, Pakistan

${ }^{5}$ Department of Pathology, Liaquat University of Medical and Health

Sciences, Jamshoro, Pakistan

Full list of author information is available at the end of the article
}

More than 70 candidate genes related to thrombophilia, blood pressure regulation, angiogenesis, hormones and lipid metabolism have been studied to detect an association with preeclampsia, however, results from these studies are inconsistent and conflicting [6].

F5 (OMIM\# 612309), MTHFR (OMIM\# 607093) and VEGFA (OMIM\# 192240) genes have been widely studied in association with preeclampsia. The products of these genes play a crucial role in the mechanism required for the normal development and functioning of the placenta $[7,8]$. The functional genetic variations in the genes affect the thrombogenic and angiogenic

(c) The Author(s). 2019 Open Access This article is distributed under the terms of the Creative Commons Attribution 4.0 International License (http://creativecommons.org/licenses/by/4.0/), which permits unrestricted use, distribution, and 
properties which lead to abnormalities of the placenta and result in preeclampsia [9-11]. The common SNVs found in association with preeclampsia include F5: c.1601G > A (rs6025), MTHFR: c.665C > T (rs1801133), MTHFR: c.1286A > C (rs1801131), VEGFA: c. $2055 A>C$ (rs699947) and VEGFA: c. $237 \mathrm{C}>\mathrm{T}$ (rs3025039) [1214]. The influence of the SNVs on disease outcome is variable among different world populations, possibly due to ethnic variations and the findings may not be generalized [15].

Pakistani population is genetically heterogeneous and have unique genetic profiles, several novel genes and alleles have been identified to help better understand the disease prediction and the course of pathogenicity. Limited literature is available for Pakistani patients explaining the interaction of genetic variations for prediction and understanding the pathogenic mechanisms of preeclampsia [16]. It is hypothesized that genotypes of SNVs of genes, crucial for development and the function of the placenta may reveal the novel genetic associations to predict the disease and its mode of manifestation. In the present study, $6 \mathrm{SNVs}$ of F5, MTHFR, and VEGFA genes have been studied in patients with preeclampsia and normal controls. This study may help to better understand the genetics of preeclampsia and the role of variants in the related genes for better prognosis and management of the disorder.

\section{Methods}

\section{Study design and participants}

The proposed case-control study was conducted after approval from the Research Ethics Committee of Liaquat University of medical and health sciences (LUMHS), Jamshoro. Written informed consent was taken from all the participants. A total of 250 pregnant women (125 cases and 125 controls) were selected from labour room, wards and outpatient department of Gynaecology and Obstetrics units. It was attempted to recruit all preeclamptic patients admitted from March 2014 to Feb 2015. During this period 187 preeclamptic patients from 20 different districts of Sindh were admitted and after following exclusion criteria, 125 cases were recruited.

\section{Inclusion and exclusion criteria}

Inclusion criteria for the preeclamptic woman was defined according to the American college of obstetrics and gynaecologists as the development of gestational hypertension (blood pressure $\geq 140 / 90 \mathrm{mmHg}$ on two events at least $6 \mathrm{~h}$ apart) and significant proteinuria $(\geq$ $0.3 \mathrm{~g}$ protein in 24 -h urine specimen or $\geq 1+$ on dipstick test) after 20 weeks of gestation in previously normotensive women. Severe preeclampsia was defined on the basis of the presence of one of the following symptoms or signs in the presence of preeclampsia i.e. blood pressure $\geq$ than $160 / 110 \mathrm{mmHg}$ (readings were taken on two events at least $6 \mathrm{~h}$ apart), proteinuria $\geq 5 \mathrm{~g}$ in $24 \mathrm{~h}$ urine specimen (or $\geq 3+$ on two urine samples at least 4 h apart), oliguria (urine volume $<500 \mathrm{ml} / 24 \mathrm{~h}$ ), cerebral or visual disturbances, pulmonary edema or cyanosis, epigastric or right upper quadrant pain, platelet count less than $100,000 / \mathrm{mm}^{3}$, presence of haemolysis, elevated liver enzymes and low platelets (HELLP) syndrome and fetal growth restriction. Eclampsia was defined as the occurrence of convulsions in women with preeclampsia [17]. Early and late onset preeclampsia was defined as the development of preeclampsia before 34 weeks and at or after 34 weeks of gestation, respectively [18].

Inclusion criteria for controls were pregnant women greater than 20 weeks of gestation in the absence of diagnostic criteria for preeclampsia until discharge of pregnant women after delivery of the baby. Subjects with the history of chronic hypertension, renal diseases, multiple pregnancy, molar pregnancy, diabetes mellitus, chronic infectious diseases, thromboembolic events, and antiphospholipid syndrome were excluded from the study. Controls recruited were matched for age, ethnicity and parity.

\section{SNVs selection and sample size}

Six SNVs F5:c.1601G > A(g.chr1:169549811), F5:c.6665A > G(g.chr1:169514323;rs6027), $\quad$ MTHFR:c.665C > T(g.chr1: 11796321), MTHFR:c.1286A > C(g.chr1:11794419), VEGFA: c. $-2055 \mathrm{~A}>\mathrm{C}$ (g.chr6:43768652) and VEGFA:c." $237 \mathrm{C}>\mathrm{T}$ (g.chr6:43784799) were included in the current study. The selection of the SNVs was based on the role of the respective gene in the placenta and the association with preeclampsia in other world populations $[3,19,20]$. Secondly, there are very few published data on the genetic role of SNVs in preeclamptic Pakistani women [16] and the selected SNVs have not been studied in association with preeclampsia in Pakistani patients.

The sample size was calculated by taking the prevalence of combined thrombophilic mutations (F5: c.1601G > A and MTHFR:c.665C > T) as described by Mello G et al. [21]. Assuming the prevalence as $19.8 \%$ in cases and $5.3 \%$ in controls, the sample size was calculated at $95 \%$ confidence level with alpha $=0.05$ and > 80\% power, using Ausvet Epitools Epidemiological calculator (http://epitools.ausvet.com.au/). The minimum sample size was calculated to be $n=95$ in each group, however, to increase the confidence, 125 subjects were selected in each group.

\section{Sample collection and DNA extraction}

Ten $\mathrm{ml}$ of venous blood was collected in $50 \mathrm{ml}$ tube containing $400 \mu \mathrm{l}$ of anticoagulant ethylene diamine tetra acetic acid (EDTA), $0.5 \mathrm{M}$ from both preeclamptic and 
normal pregnant women. Genomic DNA was extracted by inorganic method, described as previously [22].

\section{Development of tetra- primer ARMS PCR assay}

Genotyping of variants of selected genes was carried out by tetra-primer amplification refractory mutation system polymerase chain reaction (ARMS PCR) [23]. Primers were designed using PRIMER1 web tool [24]. Primer sequences were confirmed by UCSC In-Silico PCR and Blat-UCSC genome browser websites [25]. Amplification conditions were optimized and desired fragments amplified using 2720 thermocycler (Applied Biosystems). For SNVs F5: c. $1601 \mathrm{G}>\mathrm{A}$ and VEGFA: c." $237 \mathrm{C}>\mathrm{T}$, PCR performed in $20 \mu \mathrm{l}$ reaction containing $100 \mathrm{ng}$ genomic DNA, $1.25 \mathrm{mM}$ dNTP, $0.6 \mathrm{U}$ Taq polymerase, $2.5 \mathrm{mM} \mathrm{MgCl}_{2}$ buffer and $10 \mu \mathrm{M}$ of each forward and reverse outer primers and forward and reverse inner primers. PCR reaction for remaining SNVs was carried out in $20 \mu \mathrm{l}$ reaction containing $100 \mathrm{ng}$ of genomic DNA, $1.25 \mu \mathrm{M}$ of dNTP, $0.6 \mathrm{U}$ Taq polymerase, $2 \mathrm{mM} \mathrm{MgCl} 2$ buffer and $8 \mu \mathrm{M}$ of each forward and reverse outer primers and forward and reverse inner primers. PCR conditions were $95^{\circ} \mathrm{C}$ for $5 \mathrm{~min}$, followed by 30 cycles at $94{ }^{\circ} \mathrm{C}$ for $30 \mathrm{~s}$, annealing for $45 \mathrm{~s}$, extension at $65^{\circ} \mathrm{C}$ for $2 \mathrm{~min}$ and a final extension at $72^{\circ} \mathrm{C}$ for $10 \mathrm{~min}$. PCR products were separated on a $2 \%$ agarose gel (Fig. 1).
The selected samples were Sanger sequenced for confirmation of the amplicon and to validate the ARMS assays. Forward and reverse outer primers were used to amplify desired segment for DNA sequencing. Sequences of primers for ARMS assay and product sizes are mentioned in (Table 1).

\section{Statistical analysis}

Student's t-test, two-sided Fisher exact test/Chi-square test were applied to the continuous and categorical variables, respectively. A $p$-value of $\leq 0.05$ was considered as statistically significant. Genotype, allele and haplotype frequencies and Hardy-Weinberg equilibrium (HWE) were calculated. The SNVs association between cases and controls in codominant, dominant, recessive, overdominant and log-additive genetic models, and haplotype association test were performed by logistic regression by using SNPStat software [26]. Odds ratio (OR) and 95\% confidence interval were determined to find the association between allelic frequencies between the two groups. To overcome the adjustment of multiple comparisons; false discovery rate (FDR), which is the expected proportion of type 1 errors among all positive tests, controlled by applying the step-up approach of Benjamini and Hochberg was used [27]. For the

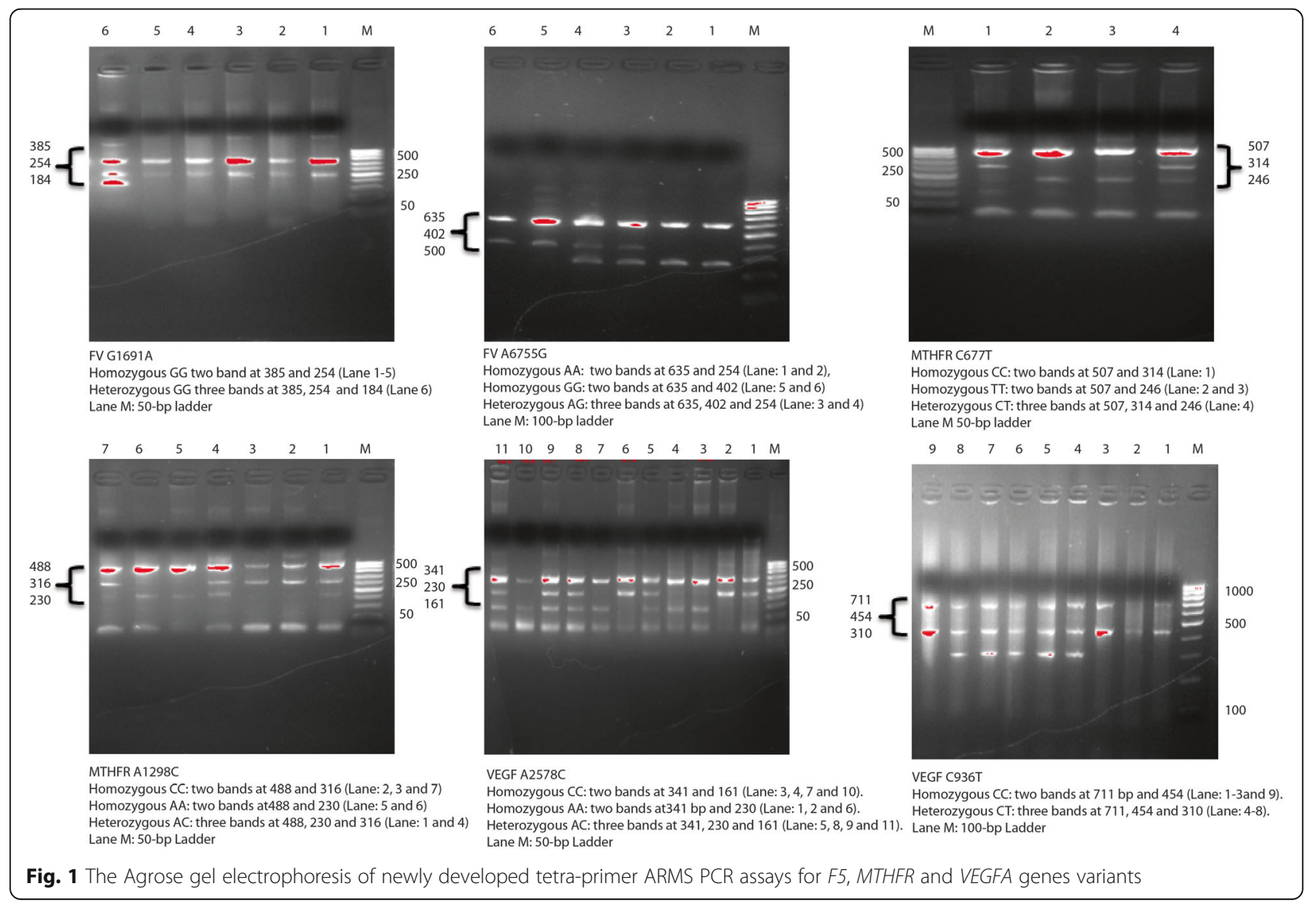




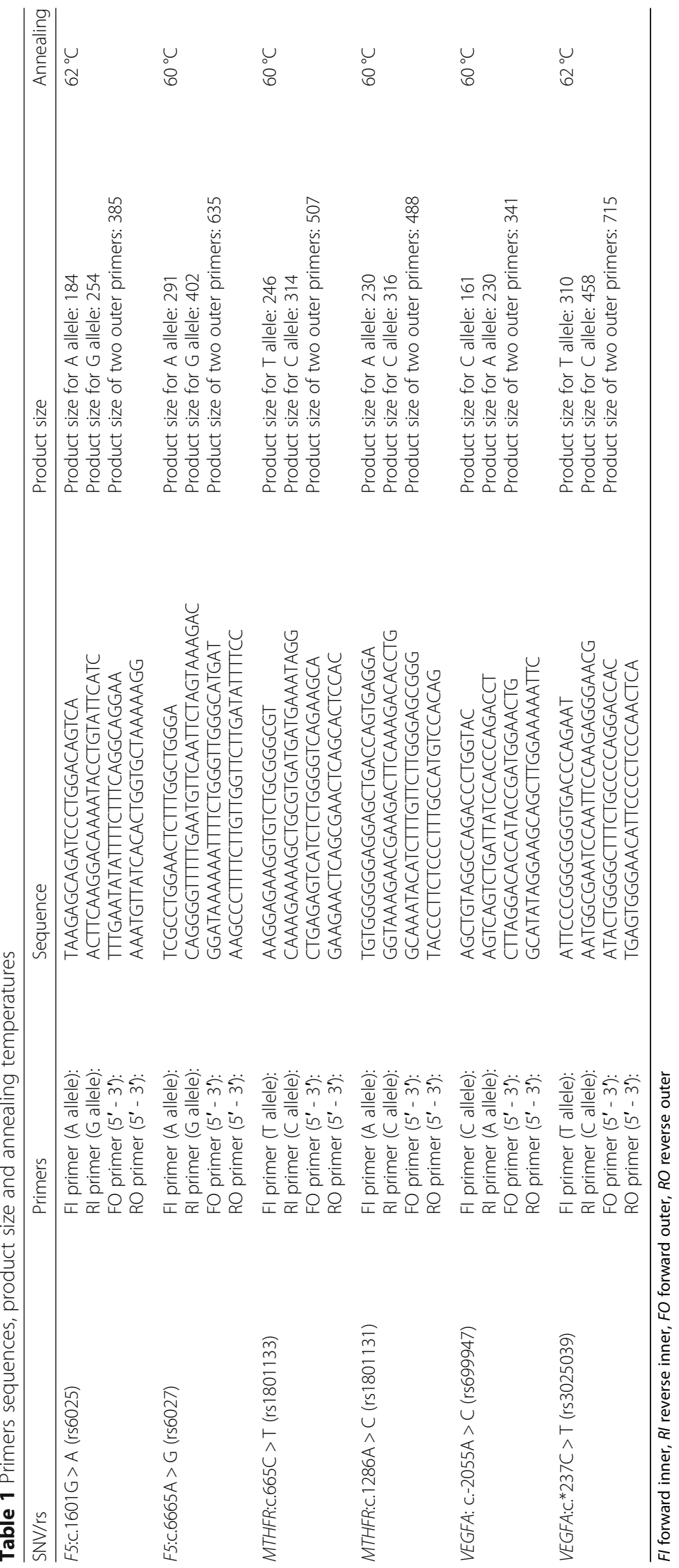


Table 2 Demographic and clinical characteristics of participants

\begin{tabular}{|c|c|c|c|c|}
\hline \multicolumn{2}{|l|}{ Variables } & Cases & Controls & $p$-value \\
\hline \multicolumn{2}{|c|}{ Age at presentation (years) } & $26.7 \pm 5$ & $26.6 \pm 4$ & 0.972 \\
\hline \multicolumn{2}{|l|}{ Age at marriage (years) } & $21.6 \pm 4$ & $21.1 \pm 4$ & 0.615 \\
\hline \multicolumn{2}{|l|}{ Height (cms) } & $152.4 \pm 8$ & $152.5 \pm 8$ & 0.610 \\
\hline \multicolumn{2}{|l|}{ Weight (Kg) } & $54.1 \pm 9$ & $54.8 \pm 10$ & 0.853 \\
\hline \multicolumn{2}{|l|}{ BMI $\left(\mathrm{Kg} / \mathrm{m}^{2}\right)$} & $23.3 \pm 4$ & $22.9 \pm 3$ & 0.882 \\
\hline \multicolumn{2}{|l|}{$\mathrm{SBP}(\mathrm{mmHg})$} & $160.4 \pm 20$ & $114.7 \pm 8$ & $<0.001$ \\
\hline \multicolumn{2}{|l|}{$\mathrm{DBP}(\mathrm{mmHg})$} & $107 \pm 17$ & $78.7 \pm 7$ & $<0.001$ \\
\hline \multirow[t]{2}{*}{ Gestational age $n(\%)$} & $<34$ weeks & $50(40 \%)$ & $27(21.6 \%)$ & 0.002 \\
\hline & $>34$ weeks & $75(60 \%)$ & $98(78.4 \%)$ & \\
\hline \multirow[t]{2}{*}{ Family history $n(\%)$} & Absent & $106(84.8 \%)$ & $122(97.6 \%)$ & $<0.001$ \\
\hline & Present & $19(15.2 \%)$ & $3(2.4 \%)$ & \\
\hline
\end{tabular}

Ethnic distribution of the preeclamptics: $n$ (\%)

Sindhi: 70 (56\%)

Urdu: 34 (27.2\%)

Balochi: 4 (3.2\%)

Pashto: 3 (2.4\%)

Punjabi: 2 (1.6\%)

Others: 12 (9.6\%)

$\%$ percentage, $B M I$ body mass index, $\mathrm{Cms}$ centimeters, $D B P$ diastolic blood pressure, $\mathrm{Kg}$ kilogram; $\mathrm{m}^{2}$ square meter, $S B P$ systolic blood pressure, $\mathrm{mmHg}$ millimeters of mercury, $n$ number. Bold fonts indicate significant $P$-value

calculation, the FDR online calculator was used (https:// tools.carbocation.com/FDR). To assess the genetic association of onset and severity of preeclampsia with SNVs that were found significant; odds ratios were estimated by multinomial logistic regression model by using SPSS version 20.

\section{Results}

\section{Demographic and clinical characteristics}

The demographic and clinical characteristics of the participants are shown in Table 2.

Among the demographic variables; age at marriage, height, weight and body mass index (BMI) were not different between preeclamptic and control groups $(P>$ $0.05)$. The gestational age at presentation and family history were found significantly different between both groups. The preeclamptic and control groups were matched for ethnicity; the ethnic distribution of the preeclamptic patients is presented in Table 2. Fifty (40\%) patients presented with early onset and $75(60 \%)$ with late onset preeclampsia whereas, $55(44 \%)$ preeclamptic women developed mild preeclampsia and $70(56 \%)$ presented with severe preeclampsia.

\section{Genotype distributions and allele frequencies}

The genotype distribution of the six SNVs in both control and preeclamptic groups were concordant with
HWE. The genotype frequencies and association test are presented in Table 3.

The F5:c.6665A > G variant showed 0.42 fold decreased risk for preeclampsia (A/G vs AA/GG: $95 \% \mathrm{CI}=$ $\left.0.21-0.84 ; P^{*}=0.038\right)$ in the overdominant model. It was also found to be associated with preeclampsia in the codominant and dominant models; however, the association lost after FDR correction.

Furthermore, significantly increased risk for preeclampsia was found with MTHFR: c. $665 \mathrm{C}>\mathrm{T}$, in dominant $(\mathrm{CT} / \mathrm{TT}$ versus $\mathrm{CC}$ : $\mathrm{OR}=2.91,95 \% \mathrm{CI}=1.29-6.57$; $\left.P^{*}=0.0497\right)$, overdominant $(\mathrm{CT}$ versus $\mathrm{CC} / \mathrm{TT}: \mathrm{OR}=$ 2.79, 95\% CI $\left.=1.18-6.59 ; P^{*}=0.046\right)$ and log-additive $\left(\mathrm{OR}=2.48,95 \% \mathrm{CI}=1.20-5.13 ; P^{*}=0.0396\right)$ models.

The significantly decreased risk was associated with CC genotype of MTHFR: c.1286A > C variant in codominant $(\mathrm{CC}$ versus $\mathrm{AA}$ : $\mathrm{OR}=0.36,95 \% \mathrm{CI}=0.18-0.72$; $\left.P^{*}=0.0392\right)$ and log-additive $(\mathrm{OR}=0.60,95 \% \mathrm{CI}=0.42$ $\left.0.84 ; P^{*}=0.0336\right)$ models whereas association in dominant and recessive models did not remain significant after applying FDR. We did not find a significant association of VEGFA: c. $2055 \mathrm{~A}>\mathrm{C}$, VEGFA: c. ${ }^{*} 237 \mathrm{C}>\mathrm{T}$ and F5: c.1601G > A with preeclampsia in Pakistani women.

Allele frequencies for MTHFR: c.665C $>\mathrm{T}$ and c.1286A $>C$ were significantly different among cases and control groups $\left(P^{*}=0.0425 ; P^{*}=0.0308\right.$, respectively). The frequencies of preeclamptics according to the onset and severity of preeclampsia were further compared with the genotype distribution of F5:c.6665A > G and MTHFR variants (Table 4).

It was observed that the frequency of heterozygous MTHFR:c.1286A > C genotype was different between preeclamptics presented at less than 34 weeks of gestation as compared to patients presented at or after 34 weeks. Preeclamptics with MTHFR: c.1286A >C, AC genotype were found to be 0.19 times less susceptible to present with early onset preeclampsia $(95 \% \mathrm{CI}=0.08$ $0.49 ; P^{*}=0.012$ ) as compared to late onset. However; MTHFR: c.1286A > C, association with severity of preeclampsia did not remain significant at BenjaminiHochberg adjusted $P$-value. The haplotype frequencies of variants in preeclamptic and controls; and linkage disequilibrium are shown in Table 5.

The G-G haplotype of F5:c.1601G > A and c.6665A > GG, and C-C and T-C haplotypes of MTHFR: c.665C > $\mathrm{T}$ and c.1286A $>\mathrm{C}$ variants showed significant association with preeclampsia.

\section{Discussion}

Preeclampsia is a complex disorder involving the role of multiple genes related to placental pathophysiology. Variations of several genes have been studied in preeclamptic patients belonging to different populations and ethnic groups [6]. Pakistani population is genetically heterogeneous and 
Table 3 Allele and genotype frequencies of SNVs in preeclamptics and controls

\begin{tabular}{|c|c|c|c|c|c|c|c|}
\hline SNV & Genetic model/ HWE (p) & Allele/Genotype & Cases $n(\%)$ & $\begin{array}{l}\text { Controls } \\
n(\%)\end{array}$ & OR $(95 \% \mathrm{Cl})$ & $p$-value & $P^{*}$ \\
\hline \multirow[t]{5}{*}{$F 5: C .1601 G>A$} & & G & $246(98)$ & $249(99.6)$ & 1.00 & 0.2125 & 0.35 \\
\hline & & A & $04(2)$ & $01(0.4)$ & $4.05(0.45-36.48)$ & & \\
\hline & N/A & $\mathrm{G} / \mathrm{G}$ & $121(96.8)$ & $124(99.2)$ & 1.00 & 0.16 & 0.28 \\
\hline & & $\mathrm{G} / \mathrm{A}$ & $4(3.2)$ & $1(0.8)$ & $4.10(0.45-37.16)$ & & \\
\hline & HWE $(p)$ & - & 0.85 & 0.96 & - & - & \\
\hline \multirow[t]{13}{*}{$F 5: c .6665 \mathrm{~A}>\mathrm{G}$} & & A & $232(93)$ & $219(88)$ & 1.00 & 0.0532 & 0.099 \\
\hline & & G & $18(7)$ & $31(12)$ & $0.55(0.30-1.00)$ & & \\
\hline & Codominant & $\mathrm{A} / \mathrm{A}$ & $109(87.2)$ & $95(76)$ & 1.00 & 0.036 & 0.077 \\
\hline & & $A / G$ & $14(11.2)$ & $29(23.2)$ & $0.42(0.21-0.84)$ & & \\
\hline & & $\mathrm{G} / \mathrm{G}$ & $2(1.6)$ & $1(0.8)$ & $1.74(0.16-19.53)$ & & \\
\hline & Dominant & $\mathrm{A} / \mathrm{A}$ & $109(87.2)$ & $95(76)$ & 1.00 & 0.021 & 0.053 \\
\hline & & $A / G-G / G$ & $16(12.8)$ & $30(24)$ & $0.46(0.24-0.90)$ & & \\
\hline & Recessive & $\mathrm{A} / \mathrm{A}-\mathrm{A} / \mathrm{G}$ & $123(98.4)$ & $124(99.2)$ & 1.00 & 0.56 & 0.71 \\
\hline & & $\mathrm{G} / \mathrm{G}$ & $2(1.6)$ & $1(0.8)$ & $2.02(0.18-22.53)$ & & \\
\hline & Overdominant & $\mathrm{A} / \mathrm{A}-\mathrm{G} / \mathrm{G}$ & $111(88.8)$ & 96 (76.8) & 1.00 & 0.011 & 0.038 \\
\hline & & $A / G$ & $14(11.2)$ & $29(23.2)$ & $0.42(0.21-0.84)$ & & \\
\hline & Log- additive & - & - & - & $0.55(0.30-1.02)$ & 0.052 & 0.104 \\
\hline & HWE $(p)$ & - & 0.12 & 0.69 & - & - & \\
\hline \multirow[t]{13}{*}{ MTHFR:C.665C > T } & & C & $224(90)$ & $240(96)$ & 1.00 & 0.0076 & 0.0425 \\
\hline & & $\mathrm{T}$ & $26(10)$ & $10(4)$ & $2.78(1.31-5.90)$ & & \\
\hline & Codominant & $\mathrm{C} / \mathrm{C}$ & 102 (81.6) & $116(92.8)$ & 1.00 & 0.026 & 0.06 \\
\hline & & $\mathrm{C} / \mathrm{T}$ & $20(16)$ & $8(6.4)$ & $2.84(1.20-6.73)$ & & \\
\hline & & $\mathrm{T} / \mathrm{T}$ & $3(2.4)$ & $1(0.8)$ & $3.41(0.35-33.32)$ & & \\
\hline & Dominant & $\mathrm{C} / \mathrm{C}$ & 102 (81.6) & $116(92.8)$ & 1.00 & 0.0071 & 0.0497 \\
\hline & & $\mathrm{C} / \mathrm{T}-\mathrm{T} / \mathrm{T}$ & $23(18.4)$ & $9(7.2)$ & $2.91(1.29-6.57)$ & & \\
\hline & Recessive & $\mathrm{C} / \mathrm{C}-\mathrm{C} / \mathrm{T}$ & $122(97.6)$ & $124(99.2)$ & 1.00 & 0.3 & 0.42 \\
\hline & & $\mathrm{T} / \mathrm{T}$ & $3(2.4)$ & $1(0.8)$ & $3.05(0.31-29.72)$ & & \\
\hline & Overdominant & $\mathrm{C} / \mathrm{C}-\mathrm{T} / \mathrm{T}$ & $105(84)$ & 117 (93.6) & 1.00 & 0.015 & 0.046 \\
\hline & & $C / T$ & $20(16)$ & $8(6.4)$ & $2.79(1.18-6.59)$ & & \\
\hline & Log- additive & - & - & - & $2.48(1.20-5.13)$ & 0.0085 & 0.0396 \\
\hline & $\operatorname{HWE}(p)$ & - & 0.12 & 0.17 & - & - & \\
\hline \multirow[t]{12}{*}{ MTHFR:C.1286A >C } & & A & $168(67)$ & $132(53)$ & 1.00 & 0.0011 & 0.0308 \\
\hline & & C & $82(33)$ & $118(47)$ & $0.55(0.38-0.78)$ & & \\
\hline & Codominant & $\mathrm{A} / \mathrm{A}$ & $61(48.8)$ & $40(32)$ & 1.00 & 0.0098 & 0.0392 \\
\hline & & $\mathrm{A} / \mathrm{C}$ & $46(36.8)$ & $52(41.6)$ & $0.58(0.33-1.02)$ & & \\
\hline & & $\mathrm{C} / \mathrm{C}$ & $18(14.4)$ & $33(26.4)$ & $0.36(0.18-0.72)$ & & \\
\hline & Dominant & $A / A$ & $61(48.8)$ & $40(32)$ & 1.00 & 0.0066 & 0.0616 \\
\hline & & $\mathrm{A} / \mathrm{C}-\mathrm{C} / \mathrm{C}$ & $64(51.2)$ & $85(68)$ & $0.49(0.30-0.83)$ & & \\
\hline & Recessive & $\mathrm{A} / \mathrm{A}-\mathrm{A} / \mathrm{C}$ & $107(85.6)$ & $92(73.6)$ & 1.00 & 0.018 & 0.0503 \\
\hline & & $\mathrm{C} / \mathrm{C}$ & $18(14.4)$ & $33(26.4)$ & $0.47(0.25-0.89)$ & & \\
\hline & Overdominant & $\mathrm{A} / \mathrm{A}-\mathrm{C} / \mathrm{C}$ & $79(63.2)$ & $73(58.4)$ & 1.00 & 0.44 & 0.58 \\
\hline & & $\mathrm{A} / \mathrm{C}$ & $46(36.8)$ & $52(41.6)$ & $0.82(0.49-1.36)$ & & \\
\hline & Log -additive & - & - & - & $0.60(0.42-0.84)$ & 0.0024 & 0.0336 \\
\hline
\end{tabular}


Table 3 Allele and genotype frequencies of SNVs in preeclamptics and controls (Continued)

\begin{tabular}{|c|c|c|c|c|c|c|c|}
\hline SNV & Genetic model/ HWE ( $p$ ) & Allele/Genotype & Cases $n(\%)$ & $\begin{array}{l}\text { Controls } \\
n(\%)\end{array}$ & OR $(95 \% \mathrm{Cl})$ & $p$-value & $P^{*}$ \\
\hline & $\operatorname{HWE}(p)$ & - & 0.069 & 0.073 & - & - & \\
\hline \multirow[t]{13}{*}{ VEGFA: C.-2055A > C } & & C & $138(55)$ & $135(54)$ & 1.00 & 0.7876 & 0.8821 \\
\hline & & A & $112(45)$ & $115(46)$ & $0.95(0.67-1.35)$ & & \\
\hline & Codominant & $\mathrm{C} / \mathrm{C}$ & $36(28.8)$ & $35(28)$ & 1.00 & 0.95 & 0.95 \\
\hline & & $\mathrm{A} / \mathrm{C}$ & $66(52.8)$ & $65(52)$ & $0.99(0.55-1.76)$ & & \\
\hline & & $\mathrm{A} / \mathrm{A}$ & $23(18.4)$ & $25(20)$ & $0.89(0.43-1.86)$ & & \\
\hline & Dominant & $\mathrm{C} / \mathrm{C}$ & $36(28.8)$ & $35(28)$ & 1.00 & 0.89 & 0.958 \\
\hline & & $A / C-A / A$ & $89(71.2)$ & $90(72)$ & $0.96(0.55-1.67)$ & & \\
\hline & Recessive & $\mathrm{C} / \mathrm{C}-\mathrm{A} / \mathrm{C}$ & $102(81.6)$ & $100(80)$ & 1.00 & 0.75 & 0.91 \\
\hline & & $\mathrm{A} / \mathrm{A}$ & $23(18.4)$ & $25(20)$ & $0.90(0.48-1.69)$ & & \\
\hline & Overdominant & $C / C-A / A$ & $59(47.2)$ & $60(48)$ & 1.00 & 0.9 & 0.93 \\
\hline & & $\mathrm{A} / \mathrm{C}$ & $66(52.8)$ & $65(52)$ & $1.03(0.63-1.70)$ & & \\
\hline & Log-additive & - & - & - & $0.95(0.66-1.37)$ & 0.78 & 0.91 \\
\hline & $\operatorname{HWE}(p)$ & - & 0.59 & 0.72 & - & - & \\
\hline \multirow[t]{5}{*}{ VEGFA:C. ${ }^{*} 237 C>T$} & & C & $229(92)$ & $222(89)$ & 1.00 & 0.2939 & 0.433 \\
\hline & & T & $21(8)$ & $28(11)$ & $0.73(0.40-1.32)$ & & \\
\hline & N/A & $\mathrm{C} / \mathrm{C}$ & $104(83.2)$ & 97 (77.6) & 1.00 & 0.26 & 0.404 \\
\hline & & $C / T$ & $21(16.8)$ & $28(22.4)$ & $0.70(0.37-1.31)$ & & \\
\hline & $\operatorname{HWE}(p)$ & - & 0.305 & 0.36 & - & - & \\
\hline
\end{tabular}

HWE hardy-weinberg equilibrium; $P^{*}$ : Benjamini-Hochberg adjusted $P$ value. Bold fonts indicate significant $P$-value

has remained an excellent source to study the relationship between gene and disease. Despite numerous genetic studies conducted in different populations [3], to the best of our knowledge, only one study reported the association of angiotensin-converting enzyme $(A C E)$ gene $\mathrm{I} / \mathrm{D}$ variant with preeclampsia in Pakistani population [16]. Preeclampsia has been related to thrombophilia and the candidate genes commonly involve F5:c.1601G > A, MTHFR: c. $665 \mathrm{C}>\mathrm{T}$ and c.1286A $>\mathrm{C}$ variants. Although various studies have reported an association of SNVs with preeclampsia [19, 28], the role of F5, MTHFR and VEGFA gene variants in Pakistani preeclamptic women have not been determined yet. Our data showed significant differences in the genotype frequencies of MTHFR: c. $665 \mathrm{C}>\mathrm{T}$, c. $1286 \mathrm{~A}>\mathrm{C}$ and $F 5: c .6665 \mathrm{~A}>\mathrm{G}$ variants in different genetic models and allelic frequencies of MTHFR: c. $665 \mathrm{C}>\mathrm{T}$, and c.1286A $>\mathrm{C}$ variants between preeclamptic women and controls.

This is the first study to report an association of F5: c. $6665 \mathrm{~A}>\mathrm{G}$ variant with preeclampsia in any population. A previous study investigated the role of 20 missense variations of the $F 5$ gene in Japanese preeclamptic women, including F5:c.6665A $>\mathrm{G}$ and indicated the significant association of only two variants rs6033 and rs6020. F5:c.6665A > G variant was not found significant in association with preeclampsia in Japanese patients [10], which is in disagreement with our findings revealing decrease risk to preeclampsia. F5:c.6665A > G results in the substitution of aspartic acid into glycine in the $\mathrm{C} 2$ terminal domain of the $F 5$ gene. The mutated residue is smaller, neutral and more hydrophobic than the wild type [29]. The substitution may affect the hydrogen bond formation, ionic interaction and rigidity of the protein. It may have an influence on the conformational changes in the protein and may be associated with unexplained activated protein $\mathrm{C}$ (APC) resistance [9-11]. F5:c.6665A $>\mathrm{G}$ has been reported as the likely benign functional variant and have significantly higher frequency among Asians and Arabians [30].

We did not find any association of F5:c.1601G > A with preeclampsia in our cohort. Though the F5 is one of the thrombophilic genes and its variants may have a key role in the development of the preeclampsia; however, the association of F5:c.1601G > A with thrombophilia and preeclampsia has remained controversial among studies; conducted on patients with different ethnic groups [31]. It has been found that F5:c.1601G > A is common in Northern India and predisposes women to preeclampsia [20]; which is contradictory to our results, though patients may have common ethnic lineages. In agreement with our study, no significant relationship of F5:c.1601G > A with preeclampsia was found in Turkish and Iranian patients [32,33]. This finding strengthens the hypothesis that $F 5$ gene variations may have a role in 


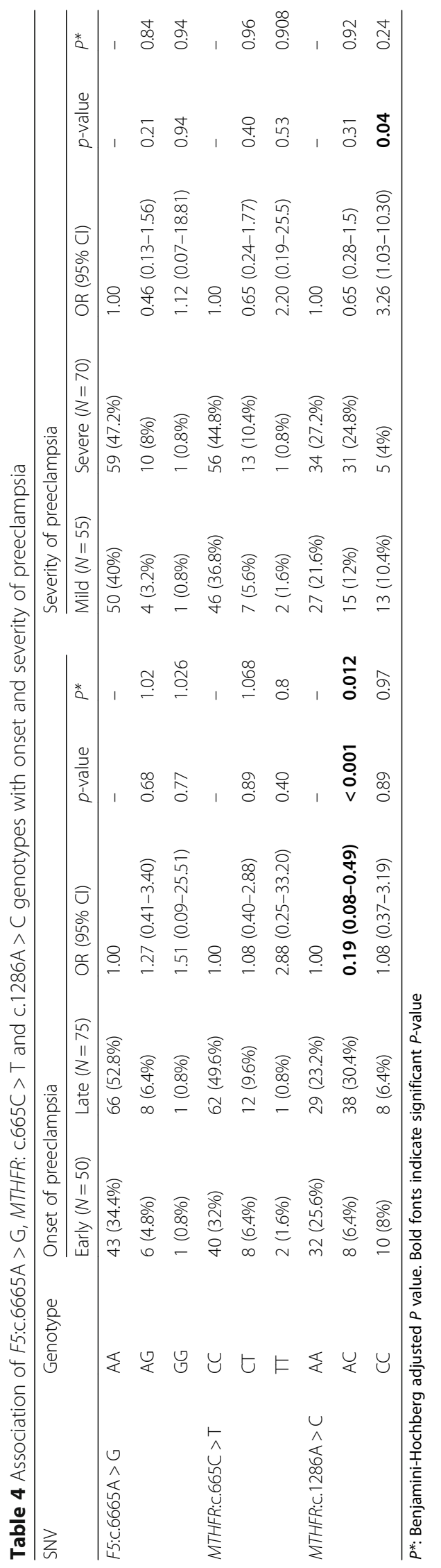


Table 5 Haplotype frequencies of F5, MTHFR and VEGFA gene variants and linkage disequilibrium analysis

\begin{tabular}{|c|c|c|c|c|c|c|c|c|}
\hline Haplotype & F5: C.1601G >A & F5: c. $6665 \mathrm{~A}>\mathrm{G}$ & Cases & Control & Total frequency & OR $(95 \% \mathrm{Cl})$ & $p$-value & $p^{*}$ \\
\hline 1. & G & A & 0.928 & 0.876 & 0.902 & 1.00 & - & - \\
\hline 2. & G & G & 0.056 & 0.120 & 0.088 & $0.35(0.17-0.72)$ & 0.0048 & 0.0144 \\
\hline 3. & A & G & 0.016 & 0.004 & 0.01 & $7.05(0.72-69.36)$ & 0.095 & 0.142 \\
\hline 4. & A & A & - & - & - & - & - & - \\
\hline \multicolumn{9}{|c|}{ Global haplotype association p-value: 0.0045} \\
\hline \multicolumn{9}{|c|}{ Linkage disequilibrium analysis: $\mathrm{D}^{\prime}=0.991, \mathrm{r} 2=0.091 ; p$-value $<0.001$} \\
\hline Haplotype & MTHFR: c.665C > T & MTHFR: C.1286A & & & & & & \\
\hline 1. & C & A & 0.672 & 0.528 & 0.6 & 1.00 & - & - \\
\hline 2. & C & C & 0.224 & 0.432 & 0.328 & $0.32(0.21-0.51)$ & $<0.0001$ & 0.0006 \\
\hline 3. & $\mathrm{~T}$ & C & 0.104 & 0.04 & 0.072 & $2.85(1.29-6.29)$ & 0.0099 & 0.0198 \\
\hline 4. & $\mathrm{~T}$ & A & - & - & - & - & - & - \\
\hline \multicolumn{9}{|c|}{ Global haplotype association $p$-value $<0.0001$} \\
\hline \multicolumn{9}{|c|}{ Linkage disequilibrium analysis: $\mathrm{D}^{\prime}=0.999, \mathrm{r}^{2}=0.116 ; p$-value $<0.001$} \\
\hline Haplotype & VEGFA: c.*237C > T & VEGFA: c.-2055A & & & & & & \\
\hline 1. & $\mathrm{C}$ & C & 0.552 & 0.54 & 0.546 & 1.00 & - & - \\
\hline 2. & C & A & 0.364 & 0.348 & 0.356 & $1.26(0.73-2.17)$ & 0.41 & 0.41 \\
\hline 3. & $\mathrm{~T}$ & A & 0.084 & 0.112 & 0.098 & $0.66(0.34-1.25)$ & 0.20 & 0.24 \\
\hline 4. & $\mathrm{~T}$ & C & - & - & - & - & - & \\
\hline \multicolumn{9}{|c|}{ Global haplotype association $p$-value: 0.38} \\
\hline \multicolumn{9}{|c|}{ Linkage disequilibrium analysis: $\mathrm{D}^{\prime}=0.9987, \mathrm{r}^{2}=0.13 ; p$-value $<0.001$, Bold fonts indicate significant $P$-value } \\
\hline
\end{tabular}

predisposition to preeclampsia, but the type of variants may vary among different populations and geographical locations.

The results of the present study exhibited the increased risk of preeclampsia with CT genotype under the overdominant model, and with the $\mathrm{T}$ allele of MTHFR: c.665C > T. In a meta-analysis, Yang et al. [34] included 57 different studies that showed TT as a risk factor for preeclampsia in Caucasians, South Americans, East Asians and Africans whereas, TT + CT was observed as a risk factor in East Asians. In the same study, a protective role was observed with $\mathrm{CC}, \mathrm{CT}$, and $\mathrm{CC}+$ CT in East Asians and CT in South Asians; however, no significant association was found in Hispanics and Middle East population. Another meta-analysis demonstrated a 1.45-fold increased risk for preeclampsia with CT genotype in East Asians [35]. Contrary to these findings and the present study, Aggarwal et al. [20] found T allele protective against preeclampsia in North Indian women.

MTHFR: c.665C > $\mathrm{T}$ is a missense variant, resulting in the substitution of alanine to valine. This leads to the production of thermolabile protein product which possesses reduced catalytic activity. The TT and CT genotypes have shown $20-65 \%$ of reduced enzyme activity to process folic acid as compared to CC genotype. Further, this variant increases the risk of hyperhomocysteinemia aggravated with folic acid deficiency [36, 37]. PolyPhen prediction indicated it as probably damaging, whereas HOPE inference showed that affected residue is bigger than wild type and located in a domain that is important for the protein activity and its interactions with other domains [29, 38]. MTHFR:c.1286A > C has been associated with reduced enzyme activity, though not with thermolability [36]. PolyPhen predicted it to be benign. HOPE analysis predicted the affected residue as neutral and more hydrophobic that might disturb correct folding $[29,38]$.

In addition, we also found the significant association of MTHFR: c. $1286 \mathrm{~A}>\mathrm{C}$ with preeclampsia. This is contradictory with the results reported in Australian [39], Dutch [40] and Mexican [41] women; where the studies have reported lack of association of MTHFR gene variants with preeclampsia which may be due to genetic heterogeneity and different ethnic backgrounds of the patients. However, the study from Southeast of Iran reported an association of MTHFR:c.1286A > C with preeclampsia suggesting its role as a risk factor for preeclampsia in Asians; though in contrast to the findings of a current study they observed AC genotype as a risk factor for preeclampsia [19].

We analysed the association of F5:c.6665A > G and MTHFR variants between early and late onset preeclampsia. Previously, MTHFR:c.1286A > C, AC and CC 
genotypes and F5:c.1601G > A, GA genotype have been associated with over 2.5-fold increased risk for early onset preeclampsia [19]. Contradictory to these findings, our study suggested less risk for early onset preeclampsia with the AC genotype of MTHFR: c.1286A >C. This suggests further research to explore the role of genotypes in severity and outcome.

VEGF is expressed in the placenta and has a significant role in its development and maintenance. VEGFA variants have been widely studied and its association with preeclampsia has been found in several studies, including Chinese, Brazilian, Hungarian and Korean patients [42-45]. However, our study negates the association of VEGFA: c. $-2055 \mathrm{~A}>\mathrm{C}$ and c. ${ }^{2} 237 \mathrm{C}>\mathrm{T}$ variants with preeclampsia in Pakistani patients. There is no significant difference found among allelic frequencies between cases and controls. These findings are in agreement with the studies of VEGFA variants, comprising of North American, Greece, Mexican and Sri Lankan patients [46-51]. The differences in results in various studies may be due to different inclusion criteria for cases and controls, sample sizes, different geographical locations, environmental factors as well as different ethnicities and genetic features.

The Pakistani population consists of at least 18 ethnic groups with more than 60 spoken languages [52]. The major ethnicities consist of Punjabi, Sindhi, Balochi, Urdu speaking, Pathan and Saraiki groups. All the ethnic groups have different genetic lineages resulting in genetic heterogeneity. Punjabi ethnics have a complex admixture of South Asian, East Asian and West Eurasian lineages, whereas, Pathan, Balochi and Sindhi share alleles with Greeks and Georgians [53-55]. While the Urdu speaking ethnic community has heterogeneous Indian ancestry [56]. Thus the genetic variations exhibit significant differences in the risk of developing various disorders and disease progression in the Pakistani population $[15,57,58]$. Majority of the preeclamptic patients in our study were Sindhi (56\%) and Urdu (27.2\%) speaking. The frequencies and genotypes of the genes analysed in this study, support the ethnic biases of the genetic variants. The frequency of the MTHFR: c. $665 \mathrm{C}>\mathrm{T}$ allele is up to $16.7 \%$ in Indian ethnic groups with the highest frequency of $7.8 \%$ of the TT genotype in the Rajput ethnicity. Whereas, MTHFR: c.1286A $>C$ allele was found higher among Dravidians of east India and south India [59]. Moreover, F5:c.1601G > A heterozygous are more frequent in European descendants and carry 5 to $9 \%$ of the $F 5:$ c.1601G > A heterozygotes, as compared to less than 1\% among Asians and African descendants [60].

In the present study, non-significant differences in BMI between preeclamptics and control groups were observed. There may be several factors which may affect the BMI, such as differences among residents of urban and rural areas, low and middle-income countries and the socioeconomic status of participants [61-63]. In the study, majority of the preeclamptics were referred from the rural areas of Sindh and had lower socioeconomic status; there was non-availability of pre-pregnancy BMI records and lack of knowledge regarding selfmeasurement. BMI in the present study was recorded at the time of presentation in both groups. The current findings are supported by a multicentre study conducted in Pakistan that did not find a significant association of BMI with preeclampsia [64]; furthermore a metaanalysis conclusively reported BMI as a weak predictor for the preeclampsia [65].

There are certain limitations in the present study. Though our sample population included some major ethnicities of Pakistan including Sindhi and Urdu ethnic groups; ethnicities of other provinces were in minority and for this reason ethnic diversities related to preeclampsia may not be generalized and require large scale studies in other provinces. Similarly, limited literature availability on genetic aspects in Pakistani preeclamptic women presented obstacles in the comparison of present study findings. We only investigated three genes, so it is possible that other genes may have a role in the development of preeclampsia in the Pakistani population.

\section{Conclusion}

MTHFR: c.665C $>\mathrm{T}$ variant was associated with preeclampsia, whereas F5:c.6665A $>\mathrm{G}$ and MTHFR: c.1286A $>C$ variants may have a protective effect against preeclampsia in Pakistani pregnant women. The significant association of SNVs for predisposition to preeclampsia may require further research for identification of more genetic variants related to preeclampsia genes. This may help to better understand the pathophysiological mechanisms of preeclampsia and may pave paths for effective therapeutic approaches. Furthermore, the development of cost effective ARMS assays may be a rapid, simple and economical method to genotype the SNVs for further studies.

\section{Abbreviations}

ACE: Angiotensin-converting enzyme; APC: Activated protein C

ARMS: Amplification refractory mutation system; BMI: Body mass index; Cl: Confidence interval; EDTA: Ethylene diamine tetra acetic acid; F5: Factor 5; FDR: False discovery rate; HELLP: Haemolysis elevated liver enzymes and low platelets; HWE: Hardy-Weinberg equilibrium;

MTHFR: Methylenetetrahydrofolate reductase; OR: Odds ratio;

PCR: Polymerase chain reaction; SNVs: Single nucleotide variants; VEGFA: Vascular endothelial growth factor A

\section{Acknowledgments}

The authors are thankful to the patients for participation in the study.

Authors' contributions

FFK: Enrolled patients and controls, Performed Laboratory experiments and statistical analysis, participated in drafting. YMW: Performed laboratory experiments and interpreted the results. FKA: participated in patient 
enrolments, performed clinical investigations. HS: Assisted in bioinformatics and sequencing. IDU: Manuscript writing and Critical review. AMW: conceived the study, supervised the laboratory experiments, and verified the data and manuscript drafting. All authors read and approved the final manuscript.

\section{Funding}

The study was funded by Liaquat University of Medical and Health Sciences, Jamshoro, Pakistan. The funding body played no role in the design of the study and collection, analysis, and interpretation of data and in writing the manuscript.

\section{Availability of data and materials}

The data of the manuscript will be provided on the request, by the corresponding author.

\section{Ethics approval and consent to participate}

The study was approved by the Research Ethics Committee of Liaquat University of Medical and Health Sciences, Jamshoro, Pakistan. Written informed consent was obtained from all participants in this study.

\section{Consent for publication}

Not Applicable.

\section{Competing interests}

The authors declare that they have no competing interest.

\section{Author details}

${ }^{1}$ Molecular Biology and Genetics Department, Medical Research Center, Liaquat University of Medical and Health Sciences, Jamshoro, Pakistan. ${ }^{2}$ Department of Biochemistry, Liaquat University of Medical and Health Sciences, Jamshoro, Pakistan. ${ }^{3}$ Department of Chemistry, Shaheed Benazir Bhutto University, Shaheed Benazir Abad, Pakistan. ${ }^{4}$ Department of Gynaecology and Obstetrics, Liaquat University of Medical and Health Sciences, Jamshoro, Pakistan. ${ }^{5}$ Department of Pathology, Liaquat University of Medical and Health Sciences, Jamshoro, Pakistan.

Received: 12 May 2019 Accepted: 2 October 2019

Published online: 23 October 2019

\section{References}

1. Duley L. The global impact of pre-eclampsia and eclampsia. Semin Perinatol. 2009;33(3):130-7.

2. Woolcock J, Hennessy A, Xu B, Thornton C, Tooher J, Makris A, Ogle R. Soluble Flt-1 as a diagnostic marker of pre-eclampsia. Aust N Z J Obstet Gynaecol. 2008;48(1):64-70.

3. Chappell S, Morgan L. Searching for genetic clues to the causes of preeclampsia. Clin Sci. 2006;110(4):443-58.

4. Sánchez-Rodríguez ENN-SS, Mendoza-Rodríguez CA, Romero-Arauz F, Morán C, Cerbón MA. Immune-endocrine alterations during preeclampsia. Open Neuroendocrinol J. 2010:3:143-51.

5. Roberts JM, Balk JL, Bodnar LM, Belizán JM, Bergel E, Martinez A. Nutrient involvement in preeclampsia. J Nutr. 2003;133(5):1684S-92S.

6. Williams PJ, Pipkin FB. The genetics of pre-eclampsia and other hypertensive disorders of pregnancy. Best Pract Res Clin Obstetr Gynaecol. 2011;25(4):405-17.

7. Pavlova E, Chemev T, Chemev A, Karagiozova Z. Pregnancy and issues with inherited and acquired thrombophilia. J IMAB-Annula Proc. 2008;1:21-2.

8. Mousa HA, Alfirevic Z. Do placental lesions reflect thrombophilia state in women with adverse pregnancy outcome? Hum Reprod. 2000;15(8):1830-3.

9. Pecheniuk N, Morris C, Walsh T, Marsh N. The factor V HR2 haplotype: prevalence and association of the A4070G and A6755G polymorphisms. Blood Coagul Fibrinolysis. 2001;12(3):201-6.

10. Watanabe H, Hamada H, Yamada N, Sohda S, Yamakawa-Kobayashi K, Yoshikawa $\mathrm{H}$, Arinami T. Association analysis of nine missense polymorphisms in the coagulation factor $V$ gene with severe preeclampsia in pregnant Japanese women. J Hum Genet. 2002:47(3):131-5.

11. Segers $\mathrm{O}$, Castoldi $E$. Factor $V$ Leiden and activated protein $C$ resistance. In: Makowski GS, editor. Advances in clinical chemistry. France: Elsevier Masson SAS; 2009;49:121-44
12. Perini JA, Cardoso JV, Berardo PT, Vianna-Jorge R, Nasciutti LE, BellodiPrivato M, Machado DE, Abrão MS. Role of vascular endothelial growth factor polymorphisms (-2578C > a,-460 T>C,-1154G $>$ a, $+405 G>C$ and + 936C > T) in endometriosis: a case-control study with Brazilians. Biomed Central Womens Health. 2014;14(1):117.

13. Al-khuriji AF. The role of vascular endothelial growth factor gene polymorphisms in recurrent spontaneous abortions in Saudi women. J Immunobiol. 2017;2(1):120-23.

14. Şamlı H, Demir B, Özgöz A, Atalay M, Uncu G. Vascular endothelial growth factor gene $1154 \mathrm{G} / \mathrm{a}, 2578 \mathrm{C} / \mathrm{a}, 460 \mathrm{C} / \mathrm{T}, 936 \mathrm{C} / \mathrm{T}$ polymorphisms and association with recurrent pregnancy losses. Genet Mol Res. 2012;11(4): 4739-45.

15. Shaikh N, Waryah AM, Devrajani BR, Rajput MI, Hayat AS, Shaikh S. IL28B rs12980275 polymorphism shows association with response to treatment in Pakistani patients with chronic hepatitis C. J Med Virol. 2015;87(5):814-20.

16. Shaheen G, Sajid S, Razak S, Mazhar SB, Afsar T, Almajwal A, Alam I, Jahan S. Role of ACE I/D polymorphism in pathological assessment of preeclampsia in Pakistan. Mol Gen Genomic Med. 2019:e799.

17. ACOG: American college of obstetricians and gynecologists. Hypertension in pregnancy. 2013.

18. Valensise H, Vasapollo B, Gagliardi G, Novelli GP. Early and late preeclampsia: two different maternal hemodynamic states in the latent phase of the disease. Hypertension. 2008;52(5):873-80.

19. Salimi S, Saravani M, Yaghmaei M, Fazlali Z, Mokhtari M, Naghavi A, FarajianMashhadi F. The early-onset preeclampsia is associated with MTHFR and FVL polymorphisms. Arch Gynecol Obstet. 2015;291(6):1303-12.

20. Aggarwal S, Dimri N, Tandon I, Agarwal S. Preeclampsia in north Indian women: the contribution of genetic polymorphisms. J Obstet Gynaecol Res. 2011;37(10):1335-41.

21. Mello G, Parretti E, Marozio L, Pizzi C, Lojacono A, Frusca T, Facchinetti F, Benedetto C. Thrombophilia is significantly associated with severe preeclampsia: results of a large-scale, case-controlled study. Hypertension. 2005;46(6):1270-4

22. Waryah AM, Shahzad M, Shaikh H, Sheikh SA, Channa NA, Hufnagel RB, Makhdoom A, Riazuddin S, Ahmed ZM. A novel CHST3 allele associated with spondyloepiphyseal dysplasia and hearing loss in Pakistani kindred. Clin Genet. 2016;90(1):90-5.

23. Ye S, Dhillon S, Ke X, Collins AR, Day IN: An efficient procedure for genotyping single nucleotide polymorphisms. Nucleic Acids Res 2001, 29(17):E88-88.

24. Collins A, Ke X. Primer1: primer design web service for tetra-primer ARMSPCR. Open Bioinformatics J. 2012:6(1):55-58.

25. Kent WJ, Sugnet CW, Furey TS, Roskin KM, Pringle TH, Zahler AM, Haussler D. The human genome browser at UCSC. Genome Res. 2002;12(6):996-1006.

26. Sole X, Guino E, Valls J, Iniesta R, Moreno V. SNPStats: a web tool for the analysis of association studies. Bioinformatics. 2006;22(15):1928-9.

27. Benjamini $Y$, Hochberg $Y$. Controlling the false discovery rate: a practical and powerful approach to multiple testing. J R Stat Soc Ser B Methodol. 1995:57(1):289-300.

28. Kupferminc MJ, Fait G, Many A, Gordon D, Eldor A, Lessing JB. Severe preeclampsia and high frequency of genetic thrombophilic mutations. Obstet Gynecol. 2000;96(1):45-9.

29. Venselaar $\mathrm{H}$, te Beek TA, Kuipers RK, Hekkelman ML, Vriend G. Protein structure analysis of mutations causing inheritable diseases. An e-Science approach with life scientist friendly interfaces. BMC Bioinformatics. 2010; 11(1):548

30. Sivadas A, Scaria V. Pharmacogenomic survey of Qatari populations using whole-genome and exome sequences. Pharmacogenomics J. 2018;18(4):590.

31. Wang X, Bai T, Liu S, Pan H, Wang B. Association between thrombophilia gene polymorphisms and preeclampsia: a meta-analysis. PLoS One. 2014; 9(6):e100789.

32. Yalinkaya A, Erdemoglu M, Akdeniz N, Kale A, Kale E. The relationship between thrombophilic mutations and preeclampsia: a prospective casecontrol study. Ann Saudi Med. 2006;26(2):105-9.

33. Malek-Khosravi S, Rahimi Z, Jalilvand F, Parsian A. Thrombophilic mutations and susceptibility to preeclampsia in Western Iran. J Thromb Thrombolysis. 2012;33(1):109-15.

34. Yang YL, Yang HL, SPK S. Meta-Prediction of MTHFR Gene Polymorphisms and Air Pollution on the Risk of Hypertensive Disorders in Pregnancy Worldwide. Int J Environ Res Public Health. 2018;15(2):326. 
35. Wang X-m, Wu H-y, X-j Q. Methylenetetrahydrofolate reductase (MTHFR) gene C677T polymorphism and risk of preeclampsia: an updated metaanalysis based on 51 studies. Arch Med Res. 2013;44(3):159-68.

36. Poursadegh Zonouzi A, Chaparzadeh N, Asghari Estiar M, Mehrzad Sadaghiani M, Farzadi L, Ghasemzadeh A, Sakhinia M, Sakhinia E. Methylenetetrahydrofolate reductase C677T and A1298C mutations in women with recurrent spontaneous abortions in the northwest of Iran. ISRN Obstet Gynecol. 2012;2012:945486.

37. Zhang Y, He X, Xiong X, Chuan J, Zhong L, Chen G, Yu D. The association between maternal methylenetetrahydrofolate reductase C677T and A1298C polymorphism and birth defects and adverse pregnancy outcomes. Prenat Diagn. 2019;39(1):3-9.

38. Adzhubei IA, Schmidt S, Peshkin L, Ramensky VE, Gerasimova A, Bork P, Kondrashov AS, Sunyaev SR. A method and server for predicting damaging missense mutations. Nat Methods. 2010;7(4):248.

39. Kaiser T, Brennecke SP, Moses EK. Methylenetetrahydrofolate reductase polymorphisms are not a risk factor for pre-eclampsia/eclampsia in Australian women. Gynecol Obstet Investig. 2000;50(2):100-2.

40. Zusterzeel PL, Visser W, Bolm HJ, Peters WH, Heil SG, Steegers EA, Steegers E. Methylenetetrahydrofolate reductase polymorphisms in preeclampsia and the HELLP syndrome. Hypertens Pregnancy. 2000;19(3):299-307.

41. Davalos I, Moran M, Martinez-Abundis E, Gonzalez-Ortiz M, Flores-Martinez S, Machorro V, Sandoval L, Figuera L, Mena J, Oliva J.

Methylenetetrahydrofolate reductase C677T polymorphism and factor $\mathrm{V}$ Leiden variant in Mexican women with preeclampsia/eclampsia. Blood Cell Mol Dis. 2005;35(1):66-9.

42. Cheng D, Hao Y, Zhou W, Ma Y. Vascular endothelial growth factor+ 936C/ T,-634G/C,-2578C/a, and-1154G/a polymorphisms with risk of preeclampsia: a meta-analysis. PLoS One. 2013;8(11):e78173.

43. Sandrim VC, Palei AC, Cavalli RC, Araujo FM, Ramos ES, Duarte G, TanusSantos JE. Vascular endothelial growth factor genotypes and haplotypes are associated with pre-eclampsia but not with gestational hypertension. Mol Hum Reprod. 2009;15(2):115-20.

44. Banyasz I, Szabo S, Bokodi G, Vannay A, Vasarhelyi B, Szabo A, Tulassay T, Rigo J Jr. Genetic polymorphisms of vascular endothelial growth factor in severe pre-eclampsia. Mol Hum Reprod. 2006;12(4):233-6.

45. Shim JY, Jun JK, Jung BK, Kim SH, Won HS, Lee PR, Kim A. Vascular endothelial growth factor gene $+936 \mathrm{C} / \mathrm{T}$ polymorphism is associated with preeclampsia in Korean women. Am J Obstetr Gynecol. 2007;197(3):271 e271-4.

46. Morrison ER, Miedzybrodzka ZH, Campbell DM, Haites NE, Wilson B, Watson M, Greaves M, Vickers MA. Prothrombotic genotypes are not associated with pre-eclampsia and gestational hypertension: results from a large population-based study and systematic review. Thromb Haemost. 2002; 87(05):779-85.

47. Papazoglou D, Galazios G, Koukourakis MI, Kontomanolis EN, Maltezos E. Association of $-634 \mathrm{G} / \mathrm{C}$ and $936 \mathrm{C} / \mathrm{T}$ polymorphisms of the vascular endothelial growth factor with spontaneous preterm delivery. Acta Obstet Gynecol Scand. 2004;83(5):461-5.

48. Chedraui P, Solis EJ, Bocci G, Gopal S, Russo E, Escobar GS, Hidalgo L, PérezLópez FR, Genazzani AR, Mannella P. Feto-placental nitric oxide, asymmetric dimethylarginine and vascular endothelial growth factor (VEGF) levels and VEGF gene polymorphisms in severe preeclampsia. J Matern Fetal Neonatal Med. 2013;26(3):226-32.

49. Andraweera PH, Dekker GA, Dissanayake VH, Bianco-Miotto T, Jayasekara RW, Roberts $C T$. Vascular endothelial growth factor family gene polymorphisms in preeclampsia in Sinhalese women in Sri-Lanka. J Matern Fetal Neonatal Med. 2013;26(5):532-6.

50. Garza-Veloz I, Castruita-De la Rosa C, Cortes-Flores R, Martinez-Gaytan V, Rivera-Munoz JE, Garcia-Mayorga EA, Meza-Lamas E, Rojas-Martinez A, OrtizLopez R, Martinez-Fierro ML. No association between polymorphisms/ haplotypes of the vascular endothelial growth factor gene and preeclampsia. BMC Pregnancy Childbirth. 2011;11:35.

51. Kim YJ, Park BH, Park H, Jung SC, Pang MG, Ryu HM, Lee KS, Eom SM, Park HY. No association of the genetic polymorphisms of endothelial nitric oxide synthase, dimethylarginine dimethylaminohydrolase, and vascular endothelial growth factor with preeclampsia in Korean populations. Twin Res Hum Genet. 2008;11(1):77-83.

52. Qamar R, Ayub Q, Mohyuddin A, Helgason A, Mazhar K, Mansoor A, Zerjal T, Tyler-Smith C, Mehdi SQ. Y-chromosomal DNA variation in Pakistan. Am J Hum Genet. 2002;70(5):1107-24.
53. Das R, Upadhyai P. Investigating the west Eurasian ancestry of Pakistani Hazaras. J Genet. 2019:98(2):43.

54. Bhatti S, Abbas S, Aslamkhan M, Attimonelli M, Trinidad MS, Aydin HH, de Souza EMS, Gonzalez GR. Genetic perspective of uniparental mitochondrial DNA landscape on the Punjabi population, Pakistan. Mitochondrial DNA Part A. 2018;29(5):714-26.

55. Yasmin M, Rakha A, Noreen S, Salahuddin Z. Mitochondrial control region diversity in Sindhi ethnic group of Pakistan. Legal Med. 2017;26:11-3.

56. Afsar NA, Bruckmueller H, Werk AN, Nisar MK, Ahmad H, Cascorbi I. Implications of genetic variation of common drug metabolizing enzymes and $A B C$ transporters among the Pakistani population. Sci Rep. 2019;9(1):7323.

57. Idrees R, Fatima S, Abdul-Ghafar J, Raheem A, Ahmad Z. Cancer prevalence in Pakistan: meta-analysis of various published studies to determine variation in cancer figures resulting from marked population heterogeneity in different parts of the country. World J Surg Oncol. 2018;16(1):129.

58. Ullah S, Aslamkhan M, Rasheed A. Molecular distribution of deafness loci in various ethnic groups of the Punjab, Pakistan. J Coll Physicians Surg Pak. 2015;25(8):573-8.

59. Saraswathy KN, Asghar M, Samtani R, Murry B, Mondal PR, Ghosh PK, Sachdeva MP. Spectrum of MTHFR gene SNPs C677T and A1298C: a study among 23 population groups of India. Mol Biol Rep. 2012:39(4):5025-31.

60. Mitriuc D, Popuşoi O, Catrinici R, Friptu V. The obstetric complications in women with hereditary thrombophilia. Med Pharm Rep. 2019;92(2):106.

61. Bodnar LM, Catov JM, Klebanoff MA, Ness RB, Roberts JM. Prepregnancy body mass index and the occurrence of severe hypertensive disorders of pregnancy. Epidemiology. 2007;18(2):234-9.

62. Neuman M, Kawachi I, Gortmaker S, Subramanian S. Urban-rural differences in BMI in low-and middle-income countries: the role of socioeconomic status. Am J Clin Nutr. 2013;97(2):428-36.

63. van Middendorp D, ten Asbroek A, Bio FY, Edusei A, Meijjer L, Newton S, Agyemang C. Rural and urban differences in blood pressure and pregnancy-induced hypertension among pregnant women in Ghana. Glob Health. 2013;9:59.

64. Shamsi U, Hatcher J, Shamsi A, Zuberi N, Qadri Z, Saleem S. A multicentre matched case control study of risk factors for preeclampsia in healthy women in Pakistan. BMC Womens Health. 2010;10(1):14.

65. Cnossen J, Leeflang M, De Haan E, Mol B, Van der Post J, Khan K, Ter Riet G. Systematic review: accuracy of body mass index in predicting preeclampsia: bivariate meta-analysis. BJOG Int J Obstet Gynaecol. 2007;114(12): 1477-85.

\section{Publisher's Note}

Springer Nature remains neutral with regard to jurisdictional claims in published maps and institutional affiliations.

Ready to submit your research? Choose BMC and benefit from:

- fast, convenient online submission

- thorough peer review by experienced researchers in your field

- rapid publication on acceptance

- support for research data, including large and complex data types

- gold Open Access which fosters wider collaboration and increased citations

- maximum visibility for your research: over $100 \mathrm{M}$ website views per year

At BMC, research is always in progress.

Learn more biomedcentral.com/submission 